\title{
Esperanças de Boaventuras: Construções da África e Africanismos na Bahia (1887-1910)
}

W lamyra Ribeiro de Albuquerque

Resumo

Este texto trata das construções em torno da África postas em circulação na cidade da Bahia, nos últimos anos do século XIX e primeiros do XX. Tendo como principal foco de análise os desfiles de dois clubes carnaval escos fundados por afrodescendentes - Pândegos d'África e Embaixada Africana - a intenção é discutir as referências que vieram a compor diversas imagens da África na Bahia da época. As recriações sobre a Á frica e os africanos foram importantes para a delimitação de lugares sócio-raciais, e aqui são analisadas como exercícios políticos de construção de identidades pela própria comunidade afrodescendente no pós-Abolição.

Palavras-chave: Bahia, África, carnaval, identidades, negro.

Estudos Afro-Asiáticos, Ano 24, ㄲo 2, 2002, pp. 215-245 
WlamyraRibeiro deAlbuquerque

\section{Abstract \\ $\mathrm{H}$ opes of Blessedness: African C onstructions and Africanisms in Bahia (1887-1910)}

This article is about African issues exposed in Bahia during the last years of the $19^{\text {th }}$ century and the first of the $20^{\text {th }}$. M ainly analyzing parades of two carnival clubs founded by African descendents - The Pândegos d'África and The E mbaixada Africana - the intention here is to discuss references which helped forming different images of Africa and Bahia at that time. The re-creations about Africa and Africans were important to delimit social-racial places and here they are analyzed as political exercises of identity construction done by the African descendants community itself during the period immediately after the abolition.

Keywords: Bahia, Africa, carnival, identity, N egroes.

\section{Résumé}

Espoirs de Bonnesaventures: Constructions d'Afrique et Africanisme à Bahia (1887-1910)

Cet article fait une analyse des constructions autour de l'Afrique qui ont parcouru la ville de Bahia, entrelafin du XIX ${ }^{\text {eme }}$ siècleet les premiers anées du $X X{ }^{\mathrm{eme}}$. N ous voulonsy débatre des références qui ont $p u$ donner lieu à différentes images d'Afrique dans I'État de Bahia de cette époque-là; notre analyse a comme thème central les défilés de carnaval préparés par deux clubs fondés par des descendants d'Africains: Folies d'Afrique et Embassade Africaine. Les récréations del'A frique et les Africains ont été importants pour la délimitation de sites socioraciaux qui, dans cet article, sont analysés en tant qu'exercices politiques de constructions d'identités, dans la période post-A bolitioniste, par la communauté des descendants d'Africains elle-même.

M ots-clés : Bahia, Afrique, carnaval, identités, N oirs. 


\begin{abstract}
“Eu, Esperança de São Boaventura, achando-me em meu perfeito juízo resolvi deminhalivrevontade fazer o meu testamento pela seguinte forma. D eclaro que sou natural da C osta D 'África não sabendo minha idade e filiação por que fui uma das victimas dehorrível crimequesechama escravidão e por muitos annos envergonhou este Brazil."
\end{abstract}

E m 1906, passados quase vinte anos do fim da escravidão, E sperança interpretou a imprecisão acerca da sua procedência como parte de uma tragédia brasileira. Foi sabendo-se estrangeira no B rasil, cativa em Santo Amaro esem informações so brea sua filiação na genérica Costa d'África, que ela conheceu e compôs imagens do seu lugar de origem. Lembranças do cativeiro eÁfricas recriadas delineavam, como num caleidoscópio, a avaliação que a africana chamada Esperança, e mais ainda, da Boaventura, fez de sua condição social. ${ }^{1}$

Bem, a tragédia da escravidão não impossibilitou os africanos de conhecerem ou adotarem signos de pertencimento que, se não eram tão precisos em termos geográficos, garantiam vínculos maisfirmes com aÁfrica e com os seus, dispersos nos doislados do Atlântico. Francisca Sallé lançou mão de dois importantes recursos identitários em 1879. D isse ser natural da Costa d'África e ex-escrava do inglês $\mathrm{N}$ icre, de quem comprou sua alforria. U sando o mesmo artifício de mencionar procedência e/ ou o antigo proprietário, Constança Teixeira distribuiu os seus bens entre africanos de nação "gallinha". ${ }^{2}$ Francisca e C onstança não estavam inaugurando nenhuma novidade ao reconhecerem a si mesmas e aos outros a partir destas referências, entretanto se pensarmos que estavam tratando das três últimas décadas do século XIX, quando havia cessado o grande tráfico e a escravidão definhava a olhos vistos, vale analisar os sentidos de denominar-se jejê, galinha, nagô e, mesmo africano. 
O $\mathrm{s}$ africanos formavam um grupo cada vez mais reduzido em Salvador naquela época. $\mathrm{N}$ as contas de $\mathrm{N}$ ina Rodrigues, em 1896 el es eram cerca de dois mil. Via-se "verdadeira extinção a passo rápido da colônia africana", disse ele (Rodrigues, 1988:100; Bacelar, 2001). Entretanto, a condição de estrangeiros estava longe da extinção. Estes estrangeiros sabiam bem que o fato de terem nascido na Africa, mesmo tendo sido trazidos ainda bem pequenos, fazia muita diferença dentro da intricada malha de hierarquias sociais na qual assentava-se a sociedade pós-escravista. Benvindo da Fonseca G alvão estava ciente desta condição ao esclarecer em seu testamento que possuía duas casas registradas em nomedos seus filhos "em razão da proibição das leis provinciais que se opunha aos africanos adquirirem bens de raiz" ${ }^{3}$ Africano era um adjetivo que real çava a condição de ex-cativo em um país que inventou engenhosas maneiras de conceder al forrias edistinguir socialmente os libertos africanos e seus descendentes a partir da cor da pele, da procedência, das conquistas pessoais e posições de prestígio. ${ }^{4}$

0 debate historiográfico sobre as continuidades possíveis e rompimentos gestados pel os africanos nas Américas tem sido pontuado por um vocabulário queinclui conceitos como crioulização, africanização, transnacionalismo e diáspora negra. Os termos/conceitos em circulação revelam não apenas um intenso debate em torno dos caminhos metodológicos eteóricos, como também sugere que interrogações sejam postas em antigas certezas: a idéia de que na B ahia preservou-se uma legítima cultura africana é uma delas. Foi esta certeza que moveu importantes estudiosos como N ina Rodrigues, Edison Carneiro, Ruth Landes e Arthur Ramos, dentre outros, a investigar e registrar o que lhes parecesse genuinamente africano, essencialmente autêntico: os africanismos.

0 empenho deles, indiscutivelmente, foi fundamental para o que conhecemos hoje da trajetória negra brasileira. M as, épreciso pôr interrogações, transformar em problemas as conclusões que fundamentaram (e, de certo modo, ainda fundamentam) as abordagens sobre os desdobramentos da escravidão na Bahia. A intenção decapturar reminiscências, influências esobrevivências patrocinou estudos de um amplo repertório das manifestações ecrenças da população negra, mas pouco contribui para pensarmos as dinâmicas que marcaram os lugares sociais da África, dos africanos e seus descendentes nos últimos anos do século XIX.

Sem dúvida, tão plural quanto as Áfricas que aportaram na Bahia eram aquelas inventadas no cotidiano de escravos, libertose 
livres. Recriações que ganhavam nitidez no modo como foram infinitamente refeitas as distinções étnico/raciais, as formas de enfrentamento das relações escravistas, os vínculos de afetividade, as crenças religiosas, mas também num extenso leque de contos, mitos e celebrações públicas moldado por inventivas memórias da África.

0 propósito deste texto é discutir as versões da África apresentadas nos desfiles carnavalescos dos primeiros anos do pós-A bolição na Bahia. Tais performances eram textos legíveis e legitimados por aqueles que estavam nas margens, e analisá-los é uma tentativa deabordar, a partir detal ótica, o desmonteda sociedade escravistana Bahia e os arranjos culturais e políticos dos afrodescendentes em construção no período. Tenho como ponto de partida a idéia de que memórias da África então construídas e confrontadas foram relevantes nas reelaborações identitárias e redefinição de arranjos socioculturais no mundo de livres e libertos. A proposta é de nos deixarmos guiar pela indignação de Esperança da Boaventura com as conseqüências do exílio forçoso dos africanos no Brasil, assim como pelo seu auto-reconhecimento enquanto al guém quefazia parte de uma comunidadedispersa em muitos territórios geográficos e simbólicos.

\section{Embaixada Africana: Q uando um Rei Etíope Veio à Bahia}

"É devido à macacada que todos vós me ledes, vereis este anno negros e diabos, diabos e negros, negros diabos, diabos negros, pois que todos os clubes vêm do inferno ou da África."

Era o que dizia um grupo de "foliões bem vestidos" na madrugada de terça-feira no carnaval de $1900 .{ }^{5}$ Pelo menos em relação a muitos clubes da época, parte desta conclusão tinha algum cabimento. Em 1908, o clubeD iabosem Folia parecia seincluir na categoria de "diabos negros" ao anunciar que era formado por " 12 africanos originários da Guiné". ${ }^{6} 0$ número de clubes, troças e máscaras quefaziam al guma men ção à África no carnaval era muito maior do que os de arlequins e pierrôs. ${ }^{7}$ O s C ongos da África, N agôsem Folia, C hegados daÁfrica, FilhosD 'África, Lembranças da África, G uerrei ros da África... eram as atrações mais comuns na festa de momo entre 1895 e 1910. "Fantasiar-se de africano" era o jeito mais divertido de a população de cor participar da festa. ${ }^{8}$

Certamente, quando eles assim se definiam na festa exibiam uma forma de pertencimento diferenciada daquela explicitada por 
Esperança da Boaventura em seu testamento. Ela, ao se reconhecer africana, marcava o seu lugar de expatriada e vítima da escravidão com o peso da proximidade da morte; já el es enfatizavam esubvertiam o lugar de marginalidade que Ihes cabia na sociedade do período, ao passo que atualizavam os vínculos que os mantinham como comunidade.

As Áfricas imaginadas, que ganhavam forma na cena carnavalesca, suscitavam interpretações e reações diferenciadas. De modo generalizado, os batuques e as máscaras avulsas eram os principaisalvosde críticas por parteda imprensa, emais ostensivamentecoibidos pela polícia. A imprensa ea polícia, em certa medi$\mathrm{da}$, viam com bons ol hos os grupos de afrodescendentes "fantasiados" de africanos; já em relação às troças e batuques a perambular pelas ruas sem qualquer disfarce, sem nenhuma fantasia, não havia tolerância, ainda que clubes ebatucadas fossem igual menteidentificados às cerimônias da religião afro-brasileira que se ouvia por toda cidade, as mal faladas al gazarras da gente de cor. Para a polícia, era a possibilidade de controle que fazia a diferença.

A justificativa da imprensa para a proibição aos batuques era a inadequação del es à estética carnaval esca, mas o queficavaà mostra era o medo dos ajuntamentos de negros a tocar pandeiros, beber ecircular livrementepela cidade. Jánão havia senhoresalançar mão de sanções e castigos e a polícia, sempre sob suspeição, estava longe de ser eficiente na demarcação de limites. ${ }^{9} \mathrm{O}$ s batuques, tidos como perigosos, difíceis de serem controlados, eram africanismos - como costumava qualificar a imprensa - a pôr em risco a ordem e o sossego ${ }^{10}$ Peter Fry, analisando as distinções entre os grandes clubes e os batuques, concluiu que os primeiros eram os "negros de alma branca", já os outros "parecem simbolizar o negro que está mais preocupado com os val ores brancos da classe dominante, ou para os quais esses valores não fazem sentido" (Fry, 1998:25). Já K im Butler distinguiu o clubeque utilizava "o carnaval para promover a acomodação racial nos mesmos moldes que os clubes brancos" - Embaixada Africana, do que o utilizava para "contestar contra a perseguição às suas tradições religiosas" Pândegos da África. N a sua conclusão, ambos os clubes foram alternativas de integração social, que tinham na cultura a sua expressão (Butler, 1998:184).

Prefiro apostar aqui noutra perspectiva de análise da participação destes clubes na farra momesca. Proponho que não capturemos a presença deles na rua apenas a partir da lógica do seu ajuste - ou não - ao model o carnaval esco deinspiração francesa. D esta 
forma, movo a minha curiosidade da assimilação/resi stência para as mensagens cifradas que, oportunamente, eram traduzidas no interior da própria comunidade afrodescendente. É por esse viés que procuro pensar como o passado africano estava compondo a experiência dos que herdaram estigmas e desafios escravistas na condição de liberdade.

É inegável quea assi milação subversiva do carnaval queestes clubes empreenderam foi um empecilho aos devaneios racistas em circulação na época e, portanto, representaram uma barreira aos esquemas hierárquicos herdados da escravidão. Contudo, o foco na polarização entre os que embranqueciam e os que se mantinham retintos, além de supor uma funcional articulação cultural negra contra ou a favor das idealizações brancas, deixa de lado 0 que me parece mais interessante: os ajustes e tensões internas nos quais a população de cor estava envol vida naqueles dias de incerteza. Ainda que eles parecessem adaptados aos ol hos das "elites", uma inevitável inquietação se corporizava nas atualizações da África. É dela que quero tratar.

No mais, não se pode dizer que os grandes clubes de temáticas africanas, E mbaixada A fricana e Pândegos d'África, desfrutassem de unanimidade. O s periódicos oscilavam entre criticá-los, ressaltando a importância de extinguir-se toda expressão de "africanismos", ou elogiá-los pela integração "civilizada" aosfestejos de momo. Entretanto, era incontestável a popularidade destes clubes. Eles atraíam o grande público ao recém-criado carnaval do fim do século XIX, na sua cruzada contra 0 entrudo. I ronicamente era o carnaval afro-baiano que garantia o sucesso do carnaval afrancesado.

Q uando o Correio deN otíciascomentou os preparativos para o carnaval de 1897 deteve-senum longo e "espirituoso" manifesto enviado pela Embaixada Africana. 0 texto, segundo o jornal, era uma nota de "pândega e verdadeira troça carnaval esca", pois a embaixada reclamava o ressarcimento dos "prejuízos para o reino da Zululândia [território da África do Sul] na ocasião do levantamento dos malês". A Embaixada dizia-se representante de uma patriótica colônia africana, ejustificava seu manifesto com 0 argumento de "não haver razão de justiça" para o açoitamento de africanos em praça pública por ocasião da revolta dos malês. Para exigir do governo local uma astronômica indenização em jardas dealgodão riscado, a E mbaixada organizaria um préstito tendo com arautosdois feiticeiros a prevenir contra o micróbio da febre amarela, seguidos deuma banda demúsicaformada pela "colônia africana da cidade" 
vestida à moda algeriana eabissínia. A cavalaria seria composta por guerreiros reais cafrer-zulos. 0 embaixador $M$ anikus, acompanhado dosseus secretários C haca eM uzilla, conclamava toda colônia a acompanhar a comitiva ao som de marimbas e instrumentos de sopro trazidos do centro da África pelo maestro Abédé. ${ }^{11}$

0 manifesto da Embaixada Africana foi muito espirituoso por tratar com ambígua jocosidade um episódio que tanto havia inquietado a sociedade brasileira em 1835 (R eis, 1986). Tornando risível o quejá havia sido trágico, dava-se por encerrado o temor às rebeliões dos africanos. Por outro lado, o fato de a revolta de 1835 ter sido tematizada só reafirmava a sua importância na memória social de uma época na qual a comunidade malê ainda contava com adeptos empenhados em guardar e manter segredos litúrgicos, como um africano queem seu testamento identificou-sedaseguinte forma: "Eu, Antonio dos Santos Lima, como mulsumano (sic) que sou eem qual religião, nasci criei-meeconservo-me esperando morrer deliberei fazer meu testamento... Sou natural de Lagos, Costa D 'África" e, solteiro "segundo as leis do Brazil". Ainda declarava: "édo meu gosto que após a morte o meu corpo fosseenvolvido deacordo com meu rito". 0 seu enterro deveria ser revestido de toda modéstia como foi sua vida, mas cabia ao seu testamenteiro e sobrinho cumprir o que estava registrado em testamento e "mais ainda o que lhe recomendei em segredo". ${ }^{12}$

$N$ as suas pesquisas $N$ ina Rodrigues aval iou que nos fins do século XIX "pelo menos um bom terço dos vel hos africanos sobreviventes na Bahia é muçulmi ou malê, e mantém o culto perfeitamente organizado". N ão era difícil, segundo ele, encontrar sacerdotes haussás e nagôs muçulmanos residindo e exercendo a sua fé no Pelourinho, Taboão eC armo com reservas, ainda numa atitude deprotesto ou medo às punições impostas em 1835. Ao entrevistar um nagô, então principal autoridade do culto na Bahia, N ina Rodrigues avaliou que havia nele um medo do "ridículo, do desprezo ou mesmo das violências da população crioula, que os confunde com os negros do candomblé ou feiticeiros" (Rodrigues, 1988:61) ${ }^{13}$ Tal temor não era tão infundado se lembrarmos da comitiva idealizada pela E mbaixada Africana para reivindicar a indenização pelos mortos na revolta dos malês: havia dois feiticeiros de Bungueira como arautos e caberia a um "poderoso desmancha feitiço" fechar o préstito. Parece que as reservas do culto, e mesmo 0 fortalecimento do candomblé enquanto a "autêntica" religião negra concorriam paraum certo desprestígio do I slã. $\mathrm{O}$ próprio $\mathrm{N}$ ina Rodrigues concluiu que 
Esperanças de B oaventuras: C onstruções da África eAfricanismos na Bahia...

[... ] o maometismo não fez prosélitos entre os negros crioulosemestiços. Se ainda não desapareceu de todo, circunscrito como está aos últimos africanos, o islamismo na Bahia se extinguirá com eles. É que o islamismo como o cristianismo são credosimpostosaosnegros, hojeainda muito superiores à capacidade religiosa deles [...] (Rodrigues, 1988:60-1)

N ina lamentava a extinção de uma herança africana decorrente de um alto grau de desenvolvimento civilizatório. A revolta dos malês foi para ele uma insurreição religiosa e não "um brutal levante de senzalas, uma simples insubordinação de escravos, mas um empreendimento de homens de certo valor. Admirável a coragem, a nobre lealdade com que se portaram os mais influentes" (Rodrigues,1988:57). A admiração dele pelos africanos adeptos do islamismo fica evidente, e mais adiante, discutirei esta predile ção. Por ora, vale notar que se não havia entre os negros baianos "capacidade" para compreender osensinamentos do I slã, por certo havia aqueles a avaliar ser a revolta um episódio capaz demobilizar festivamente adeptos de outros cultos.

A Embaixada Africana começou a aparecer na imprensa em 1895, semprereferida pela sua habilidade para atrai r uma compacta massa popular, atenta, seduzida pela exibição de instrumentose danças africanas. 0 tom de pilhéria dos embaixadores enchia as páginas dos jornais locais, sempre elogiosos da sua criatividade. No manifesto de 1897, enfatizou-se que "para provar que o papelório não é privilégio desta terra das palmeiras, um possante animal carregará o archivo africano, onde virão todos os documentos concernentes à missão que tem a cumprir a embai xada na Bahia". Se a oralidade estruturou política e cultural mente as sociedades africanas, a informação sobreo "papelório" que teria atravessado o Atlântico poderia ser um reforço do absurdo, do carnaval esco daquela comitiva. Por outro lado, a inabilidade da polícia para decifrar a escrita árabeem 1835 - "os papéis malês" - , ainda era motivo de zombaria em 1897. Afinal, achincal har a burocracia, o "papelório", dos poderes públicos parecia render al guma diversão.

D epois de uma grande expectativa propalada pelos jornais em torno do desfile daquele ano, o destaque da Embaixada Africana não foi o levante malê. A África então trazida à cena carnavalesca tinha como personagem principal uma caricatura do rei etíope $M$ enelik. Referido em um panfleto distribuído pelo clube como 0 "vitorioso negus dosnegus", M enelik regularmente ocupava as páginas dos jornais locais. 0 Correio de N otícias de março de 1900 publicou uma longa matéria ironizando o governo dele. 0 periódico 0 apresentava com um déspota africano excêntrico, que pla- 
nejava visitar Paris. T omando como informante o alemão Cleveland $\mathrm{M}$ offet, o jornal tecia comentários divertidos sobre os meios pelosquais M enelik exercia o poder naÁfrica. Contou-sequefazia parteda sua rotina rondas diárias com a inten ção deflagrar a população em qualquer pequeno delito, e que a cada domingo promovia-se um farto jantar real ao ar livre, no qual todos os generais do governo, proibidos de olharem para o soberano enquanto ele comia, se posicionavam na mesa de modo a garantir que o rei também não fosse visto pela platéia popular. ${ }^{14} \mathrm{O}$ exótico, risível, bizarro era assim associado à imagem do poderoso soberano africano que no desfile de 1897 ressuscitava com honras festivas os mortos na revolta de 1835. F azendo jus à caricatura imponente enegra de M enelik no carnaval de 1897, o "seu trono era bem alto e ao abojo de um grande chapéo de sol". ${ }^{15}$

N ão era bem esta imagem que os italianos derrotados em Adwa, território da Abyssinia, em 1896, tinham do rei M enelik II (notequeéapenas um ano antes do desfileda Embaixada Africana com a sua representação). $\mathrm{N}$ a opinião de $\mathrm{H}$ arold $\mathrm{G}$. M arcus, $\mathrm{M} \mathrm{e}$ nelik sefirmou como o principal obstáculo aos propósitos imperial istas europeusna África, eao mesmo tempo investiu na expansão das frontei ras do seu próprio império com muita habilidadediplomática e perspicácia, tendo governado a Etiópia até1913 (M arcus, 1975:2).

A vitória etíope sobre os italianos não foi apenas bélica, já que admitir a derrota para homens de "raça inferior" significava pôr em risco sólidas convicções imperialistas eraciaisentão mediadoras das relações entre os "ocidentais" e o resto do mundo. Buscando preservá-las, os europeus passaram a descrever os etíopes como brancos, atribuindo a eles qualidades e características dos grandesimpérios do ocidente. $\mathrm{N}$ aliteratura européia, $\mathrm{M}$ enelik podia ser representado como um herói romântico ou um grande estadista, como na comparação deSkinner entreM enelick eBismarck, para ele, dois brilhantes estadistas de igual inteligência (ibidem: 215).

Confrontando os europeus, o rei assegurou o domínio sobre o seu território eameaçou as certezas de superioridade branca e européia, mas nada podia fazer em relação às manipulações de sua imagem. Como diria M ary L ouise Pratt, tratava-se de um empreendimento de anticonquista, na medida em que os europeus naturalizavam as diferenças e estabeleciam semel han ças culturais a partir de seus objetivos expansionistas, elaborando edivulgando convenientes representações do outro flagrado pelas lentes de viajan- 
tes, literatos, diplomatas e jornalistas (Pratt, 1999). ${ }^{16} \mathrm{~V}$ ale aqui lembrar do alemão que, passando-se por isento observador, deu a conhecer aos leitores do Correio de $\mathrm{N}$ otícias as suas impressões sobre M enelik como um ridículo déspota. A ambigüidadeque pairava acerca deM enelick fica ainda mais real çada se atentarmos para a existência deum jornal mensal, "noticioso, literário e crítico dedicado aos homens de cor" quetinha seu nome como título. N o primeiro número esclareceu-se a homenagem do seguinte modo:

Fundou-se então este jornal o qual buscou adquirir um nome que, não deveria, mas era, esquecido dos homens de cor, é esse nome o de M enelick II, o grande rei da raça preta [...]. ${ }^{17}$

O M enelik foi fundado em São Paulo, no ano de 1915, portanto, dois anos depois da morte do soberano etíope e em meio à atmosfera de denúncias e reivindicações da imprensa negra na capital paulista. Sem dúvida, um contexto bem distinto da sociedade baiana do final do XIX, constatação que não esvazia a importância de pensarmos sobre os paral elismos e distinções destas apropriações da figura de $M$ enelik. Por enquanto, três questões: qual o lugar da representação de $M$ enelik veiculada pela imprensa baiana? A partir de quais referências ele era trazido às ruas pela E mbaixada Africana? Q uais as possibilidades de leitura da África suscitadas pela representação do poderoso rei etíope?

Edison Carneiro informou que a Embaixada Africana teria sido fundada por $\mathrm{M}$ arcos $\mathrm{C}$ arpinteiro, um axogún - aquele encarregado do sacrifício ritual dos animaisa serem ofertadosaos deuses afro-brasileiros - um importante cargo hierárquico, de um terreiro de candomblé situado no Engenho Velho (Carneiro, 1974:122). Como vários autores já ressaltaram, os vínculos entre terrei ros de candomblé e agremiações carnaval escas da população decor sempreforam muito fortes (Félix \& N ery, 1993). Aqui aimportância destes vínculos está no trânsito de concepções e perspectivas traçadas dentro da comunidade afrodescendente depois de extinta a escravidão. N aquela conjuntura, mais do que espaços de preservação de tradições, os terreiros de candomblé foram territórios decriação eredefinição desímbolos, a partir deuma seleção de informação sobre a África e os africanos no Brasil. ${ }^{18}$ Longe de preservarem-se sobrevivências, nas casas de cultos adequavam-se/selecionavam-se referências. Sendo axogún e carnavalesco, M arcos Carpinteiro, possivel mente, contribuiu para a exibição desta África fragmentada einclusiva na qual cabia da revolta dos malês ao rei M enelik. Tratava-se de uma África traçada a partir da experiência 
dos africanos no cativeiro, mas que a transcendia carnavalescamente e na qual passado e presente se confundiam na extravagância dos reinos e lealdade da "colônia africana".

$\mathrm{Na}$ busca por mais informações sobre os integrantes da Embaixada Africana recorri aos seus testamentos e inventários. D estemodo localizei Saturnino G omes, conselheiro em 1902, um ano de intensa campanha contra a participação dos clubes "africanos". U ma concorrida disputa entre um sobrinho e dois filhos ilegítimos pela herança deste próspero comerciante de materiais de construção me permitiu conhecer um pouco da sua condição social. Sendo proprietário de uma casa denominada " 0 23", provavelmente uma homenagem às lutas pela independência na Bahia, Saturnino G omes ocupava, desde os últimos anos do século XIX, um terreno na avenida mais importante da cidade: a Sete de $\mathrm{Se}$ tembro. As suas propriedades estavam todas localizadas nos distritos centrais de São Pedro e Vitória.

$N$ as primeiras décadas do século $X X$, época de agitadas reformas urbanas, o comerciante conseguiu acumular muitos bens. Entre eles, um piano alemão avaliado em três contos de réis, além de certos luxos como uma vitrola, 64 discos, uma mobília de sala com 23 peças euma "novíssima” máquina de escrever. Preocupado em não ser prejudicado na partilha dosbens emanter a casa comercial em funcionamento, o sobrinho de Saturnino G omes fez questão de inserir no inventário uma minuciosa lista de contas a serem pagas. Segundo a prestação de contas do sobrinho/inventariante o comerciantefizera grandes negócios no Rio deJ aneiro, contraindo débitos que ainda não tinham sido liquidados devido às vultosas somas envolvidas. A idas e voltas para a capital federal podem ter contribuído para o empenho do comerciante na farra momesca, visto que naquela cidade os investimentos no carnaval já não eram desprezíveis. ${ }^{19}$

Também compunha a diretoria outros nada afortunados, a exemplo de Esterico da Conceição, artista, registrado no inventário dos seus parcos bens como pardo, eQ uintiliano M acário, também pardo e artista, que além de funcionário público era proprietário de uma rocinha com casa de morada às margens do rio $\mathrm{C}$ amurujipe, no $C$ andeal Pequeno. Ambos eram moradores do distrito de Brotas. Esteenglobava áreas mais distantes do centro comercial da cidade, local de antigos engenhos, eainda era ocupado por pequenas roças e sítios para a criação de porcos e aves. Ainda que os poucos e derradei ros africanos estivessem dispersos por toda a cidade nos últimos anos do século XIX, o distrito de Brotas reunia 
uma boa parte deles. G ente com Cornélio de Pedroso, proprietário de um pequeno sítio num lugar chamado Pomar e vizinho de vários outros africanos. ${ }^{20}$

A recorrenteeimprecisacategoria deartistanão ajudamuito a descobrir do que eles se ocupavam especificamente. Podiam ser artistas os pedreiros, marceneiros, sapateiros, ferreiros, etanto outrosartífices. É provável queeles fossem os encarregados de conceber e construir os carros alegóricos. É comum encontrarmos homens de cor nestas funções na documentação do período. Em geral estavam instalados em pequenas ten das e oficinas espal hadas pelas ruas centrais da cidade, ou reunidos nos cantos de trabal hadores ainda existentes (Reis, 1993; 2000). Assim organizados, a viabilidade do ofício estava garantida, pois facilitava o contato com quem precisasse de seus serviços.

J oão J osé Reis considera a possibilidade de os cantos refletirem, no fim do XIX, a configuração de "uma identidade nagô na Bahia de então, a qual se manifestava através de rituais religiosos, inclusive, talvez de rituais feitos nos âmbitos dos cantos" (Reis, 2000:223). Não épossível afirmar que os componentes da E mbaixada integrassem algum dos cantos, mas também não é absurdo imaginar queeles circulassem nestes espaços buscando quem seinteressasse por seus préstimos. Construíam-se, assim, zonas de circulação das imagens daÁfrica - terreiros, cantos, distritos perifé ricos - que exibidas no carnaval ganhavam formas, polifonias e sentidos. Eranestas zonas quea "colônia africana" na Bahia era alegoricamente constituída.

N o carnaval de 1898, o clubeenviou à redação do Correio de $\mathrm{N}$ otícias um tel egrama assinado por $\mathrm{M}$ anikus, informando a chegada de um vapor com a Embaixada e convocando a "colônia africana" para receber aos "seus ilustres representantes no caes de São J oão" ${ }^{21} 0$ tel egrama seguia informando que, para reiterar o "apreço" dos africanos da cidade aos seus patrícios recém-chegados, "mandaram fabricar na França um lindo carro de madrepérola para transportá-los". A piada devia ser óbvia: recepcionar um soberano africano com sofisticação francesa. Produtos e costumes franceses eram as grandes aspi rações das elites locais e cujo contraponto às pretensões de afrancesamento estava justamente nos indesejáveis "africanismos" tão evidentes na capital baiana. E, como ficou célebre nos discursos dos viajantes, era no cais onde se podia ver estivadores, vendedoras com seus balaios e bandejas, carregadores de toda espécie de carga, moleques em pequenas compras... gente de cor a exibir trajes, vocabulário e comportamentos nada 
"civilizados". ${ }^{22}$ Assim, carnavalizava-se a África pondo-a em contraste com as idealizações culturais construídas a partir das sociedades européias, especialmente a francesa. $M$ ais do que isso: a França e os baianos afrancesados.

Em novas configurações geográficas, a África mitificada de $M$ enelick fazia fronteira com muitos lugares nas ruas da Bahia. 0 clube Expedição ao Transvaal foi considerado, em 1900, um dos mais freqüentados e animados. 0 tema: a guerra dos bôers, que aconteceu na África do Sul entre 1899 e 1902. Foi em Transvaal onde se concentrou a população bôer ou afrikâner, e também onde sedescobriu, em 1886, valiosasjazidas de ouro. N a avaliação do historiador G odfrey N . U zoigwe, aquela foi a última grande empreitada inglesa em território africano, encerrada com a assinatura doTratado deVereeniging que, de certo modo, só reiterava a sua supremacianaÁfrica do Sul (U zoigwe, 1985:43-67). A Expedição distribuiu um manifesto de S. M . O Poder, ironizando a investida inglesa:

Eloquência é o canhão, a bala é o verbo.

[...]

O spapa-bifes daÁfrica, em nomede uma fantasmagoria, a que denominam liberdade não cessam de abater e dizimar as levas de J ohns [...] Deante desta afirmação aflitiva vendo começar a enfraquecer o hercúleo pulso da invictaAlbion, decide pôr-meà frente da $G$ rande Expedição ao Transvaal que ahi vedes. N esta expedição não notareis distinção de povos. Reuni elementos de pontos os mais variados. Todos são admitidos em minhas fileiras: H indus, Beduínos, Zulus, selvagens, bárbarose ci vilisados. E ainda irei buscar gente a todas as terras, a todas as partes, a todos os cantos no M ississipe, no Peru, na Arábia. ${ }^{23}$

N esta espécie de manifesto pacifista, os carnaval escos mostraram-se bem informados acerca das disputas políticas na África do Sul, e divulgavam uma leitura da farra carnavalesca enquanto momento de convivência entre diferentes. C onvivência, na verdade, nada pacífica, principalmente nos primeiros anos do século $X X$, quando a polícia assume cada vez mais o papel de regulador das formas de ocupação do espaço da rua. Em 1906, por exemplo, foram proibidos pelo chefe da segurança pública, J oão Santos, "as africanizações pelos grupos representando usos e costumes da Costa d'África". . ${ }^{24}$ Recurso, em parte, malsucedido se observarmos que naquele mesmo ano e nos seguintes a Abyssínia de M enelik continuou a ser tema de grupos como a T ribu dosI nocentes, a declarar em seu panfleto que levaria para o carnaval não os "tistanados naturaes", mas "os temidos gênios que imperam na África, rica e cobiçada pela força de sua magia, fazendo pasmo às demais partes 
da orbeque presentementetremem entregues, como vós, às loucuras imponderáveis desta festa sem par" ${ }^{25}$ E ra a vitória de $M$ en elick que continuava a ser re-significada deste outro lado do Atlântico. As guerras que envolviam a partilha da África eram rapidamente noticiadas aqui. $\mathrm{N}$ ão me parece coincidência que os conflitos nos quais a vitória dos europeusfoi mais difícil - no caso dosbôers ou impossível - na questão etíope - , os quemaisfreqüentemente fossem ritualizados nas ruas da cidade. $M$ as, a proibição do chefe de segurança foi eficiente se notarmos que o clube Filhos da África conseguiu licença do delegado M adureira de Pinho para participar do carnaval, com a condição de obedecer à postura. ${ }^{26}$ Resta imaginar como osFilhos da África saíram às ruas sem africanizar-se. T alvez, dentro da lógica racista policial, houvesse africanismos mais aceitáveis do que aquel es de que o clube se utilizou.

Podemos agora pensar sobrea admiração de $\mathrm{N}$ ina Rodrigues àE mbaixadaAfricana. Para elehavia ali "aidéia dominantedosnegros mais inteligentes, ou melhor adaptados, a celebração de uma sobrevivência, de uma tradição" (Rodrigues,1988:180). Ao contrário dos jornal istas da época, empenhados em acabar com os temíveis batuques, o estudioso das práticas africanas na Bahia estava mais atento às variações da África trazi das às ruas. C abelembrar da sua admiração pelos malês para entender o seu ponto de vista. $M$ ergulhado em suas idéias racialistas, $N$ ina Rodrigues via na mítica África apresentada pela Embaixada Africana uma redenção da barbárie. Como os europeus surpreendidos com o poderio dos etíopes, ele reconhecia a superioridade de certos povos africanos, e concluiu ser preciso distinguir

[...] entre os verdadeiros negros e os povos camitas que, mais ou menos pretos, são todavia um simples ramo da raça branca ecuja alta capacidade de civilização se atestava excelentemente na antiga cultura do Egito, da Abissínia [Etiópia] e etc. (Rodrigues, 1988:269, ênfases minhas).

A performance da Embaixada Africana constituiu-se mesmo num texto polifônico. Sehavia, por parteda grande imprensa, tentativas de ridicularizar $\mathrm{M}$ enelik, $\mathrm{N}$ ina R od rigues a lia como o reconhecimento do valor de certos africanos, pertencentes a um ramo secundário da raça branca. N ão há como duvidar de que a propaganda pró-embranquecimento de M enelick também cruzou 0 Atlântico e aportou nas aspirações racialistas de N ina Rodrigues, ainda que os propósitos do médico maranhense fossem diferentes daquelas dos viajantes ingleses. $\mathrm{N}$ a sua opinião, clubes como os Pândegos d' África expressavam uma imagem inadequada das so- 
ciedades africanas, já a E mbaixada Africana tinha o seu "motivo e personagens tomados aos povos cultos da África, egípcios, abissínios, etc." É hora de abordar porque os Pândegos d'África era 0 principal contraponto à África baiana desejada por N ina Rodrigues.

\section{Pândegos d' África: A África "Inculta" dos N agôs}

0 Correio de $\mathrm{N}$ otícias, comentando o carnaval de 1897, assinal ou que o clube Pândegos d' África havia atraído às ruas "o povo e especialmente os africanos; mas africanos de lei acompanhavam-nos entrefesta". ${ }^{27} \mathrm{~A}$ B ahia o definiu como um grupo perfeitamente caracterizado, a soar instrumentos prediletos e can ções africanas. ${ }^{28} \mathrm{~A}$ ênfase na africanidade do clube e do público para M anoel Q uerino, em 1897, se explicava pelos elementos "mouros", os instrumentos da charanga que seriam os mesmos utilizados no "feitichismo" e, principalmente, pelo acompanhamento "das africanas [que] tomadas de verdadeiro entusiasmo, cantavam, dançavam e tocavam durante todo o trajeto, numa alegria indescritível" (Q uerino, 1988:62-3).

Os comentários de $\mathrm{N}$ ina Rodrigues sobre o Pândegos d'África tiveram como objeto o desfile do clube em 1899, do qual constava três carros alegóricos: o primeiro com o rei Labossi, à margem do Zambeze, em companhia de seus ministros - Auá, 0 man e Abató; o segundo, com dois figurões influentes da corte - Barborim eR odá; o último representando a cabana do feiticeiro Pai 0 jô e sua mulher com o caboré do feitiço, a dar sortea tudo ea todos. Além dos carros ainda havia a charanga africana que "vinha a pé com seus instrumentos estridentes e impossíveis".

Sob o olhar de N ina Rodrigues, o desfile dos Pândegos d' África transformou-se num "candomblécolossal", pela "compacta multidão denegrosemestiços cantando cantigas africanas, sapateando as suas danças e vitoriando os seus ídolos ou santos que lhes eram mostrados do carro do feitiço". U ma "vingança dos negros feitichistas", alvo de tenazes investidas policiais no período, a impor com instrumentos e "canções da terra natal" o culto jeje-iorubano na celebração carnavalesca. U ma exibição da "África inculta queveio escravizada para o Brasil" (Rodrigues, 1988:180). Q uero lembrar que o médico maranhense publicou, entre 1896 e 1897, uma série de artigos sobre "as práticas mágicas" dos negros 
Esperanças de B oaventuras: C onstruções da África eAfricanismos na Bahia...

baianos, quecompuseram, em 1900, o livro 0 Animismo Feitichista (Rodrigues, 1935).

Em suas avaliações sobre o carnaval, $N$ ina Rodrigues não perdeu a oportunidade de mais uma vez ressaltar a predominância sudanesa na Bahia, ao afirmar que foi a África dos iorubanos, jejês e minas que sobreviveu entre a população crioula. Teriam sido eles, e não os angolas, que tomaram da África banto os motivos e idéias dos clubes carnaval escos. No desfile dos Pândegos, a informação mais precisa foi o rio Zambeze, uma importante entrada para o interior daÁfrica oriental no período das investidas colonialistas. Infelizmente, ainda não encontrei notícias sobre o rei Labossi, mas é possível que ele tenha sido um personagem ficcional, útil na encenação de um reino africano, cujo rei cercado de ministros, referendado pelo poder de um feiticeiro, detinha o poder de modo soberano. Era esta África tão mítica quanto visível numa cidade ondeos batuques perturbavam o sono eosplanos das elites.

$N$ as informações de Edison Carneiro, o Pândegos d' África foi fundado por Bibiano $\mathrm{C}$ upim, o vice-presidente do conselho diretório do clube em 1900 (Carneiro, 1947: 123). Bibiano Cupim tinhaum vasto currículo: foi açougueiro, banqueiro dejogo bicho, carpinteiro (como o axúgum que fundou a Embaixada Africana), prior da ordem terceira do R osário e membro da Sociedade Protetora dos D esvalidos (Butler, 1998:139). Tendo se declarado mestre de obras em 1933, el e herdou de sua família certo patrimônio. F oram três casas à rua Luís G ama, no distrito de Sant'Anna, e outras duas no distrito de Santo Antônio, sendo uma na Rua da M atança no Barbalho, onde deveria funcionar o seu açougue e o já rentável negócio do jogo de bicho. ${ }^{29} \mathrm{Com}$ trânsito por tantos ambientes, Bibiano Cupim se me parece um personagem importante na cena político-cutural daépoca. Estendendo asua influência por tantos espaços e ao mesmo tempo constituindo o seu lugar social a partir deles, ele sintetizava al gumas formas de inserção e leituras do mundo de um homem de cor no pós-A bolição. D a banca de bicho à ordem terceira do Rosário muitas compreensões acerca das mudanças provindas da Abolição e da República estavam sendo filtradas pela população de cor.

Também havia na diretoria do clube outros senhores de alguns bens. U m deles era o preto Silvério Antônio de C arvalho, artista edono deduas casas, seis casinhas eum terreno a Rua N ova do Q ueimado, em Santo Antônio. ${ }^{30} 0$ outro, Juvenal Luiz Souto, era proprietário de uma casa térrea a Rua do Alvo, em N azaré, um sobrado no distrito de Sant'Anna, onde guardava uma mobília aus- 
tríaca e um piano al emão, e um terreno na Estrada das Boiadas. Este mestre em carpintaria tinha sob suas ordens vários trabalhadores manuais executando obras em diversos prédios públicos, como delegacias de polícia e o Superior T ribunal de ustiça. A sua situação assemel hava-seà deum empreiteiro ou mesmo capitão de canto. Juvenal Souto também ocupou uma vaga na Escola de Aprendizes Artífices, onde pode ter conhecido $M$ anoel Q uerino que, em 1900, presidia os Pândegos d' África. ${ }^{31}$ Este, sem dúvida, foi um dos mais importantes integrantes do clube.

$M$ anoel $Q$ uerino era um personagem curioso na Bahia da época. $N$ ascido mulato em Santo Amaro, foi tutelado por um professor, ocupou um cargo público de menor importância na Secretaria de Agricultura e fundou o liceu de artes e ofícios. Envolvido nas grandes questões de seu tempo, foi abolicionista e republicano, usando de uma ironia que não isentou de críticas hábitos "requintados" da época. ${ }^{32} \mathrm{~A}$ M anoel Q uerino comumenteéatribuída a pecha de imprevidente nas palavras e atitudes; um colecionador de desafetos (Q uerino, 1988:2). M as, sobreeletambém já foi dito que "muita coisa que havia passado despercebida ao próprio $\mathrm{N}$ ina Rodrigues não escapou ao olhar investigador do modesto professor negro, que nos desvãosignorados do candomblé do $\mathrm{G}$ antois ou diretamente em sua residência no $M$ atatu $G$ rande, se rodeava de velhos africanos, pais e mães de santo" (ibi dem:14). Em 0 C olono $\mathrm{N}$ egro como $\mathrm{F}$ ator de Civilização Brasil leira ele afirma que o escravo africano era trabal hador, econômico e previdente, qualidades que os descendentes nem sempre conservavam (ibidem:35). A sua admiração pelos africanos é transparente em todos os seus textos.

Do mesmo modo que Bibiano Cupim, Manoel Querino também fez parte da Sociedade Protetora dos $D$ esvalidos, uma associação fundada em 1832 pelo africano livre e ganhador M anoel V ictor Serra. Inicialmente denominada I rmandade de N ossa Senhora da Sociedade Amparo dos D esvalidos previa, entre as suas finalidades, associar "homens de cor preta" e contribuir para a compra da al forria dos que ainda fossem cativos. Parao antropólogo J ulio B raga, a sociedade era uma importante agência de prestígio e auxílio mútuo, principalmentelogo após a A bolição, quando o número de recém-ingressos ultrapassou o de antigos sócios. M anoel Q uerino teve al guns problemas na instituição. U ma vez demitido do quadro de sócios, entre 1892 e 1894 ele tentou ser readmitido, só o tendo conseguido depois de muitos acordos com os membros do conselho (Braga, 1987). A fama de colecionador de 
desafetos parecia ter sentido, já que a exclusão de sócios era um expediente muito incomum.

$M$ anoel $Q$ uerino e Bibiano C upim também foram associados do Centro 0 perário. Portanto, a presença de ambos à frente dos Pândegos d'Africa de modo algum era acidental. Ainda em 1900, na mesma nota distribuída aos jornais informando sobre o resultado da elei ção para dirigentes do clube, el es diziam que esperavam não serem taboqueados no carnaval seguinte. ${ }^{33}$ Taboquear, lograr, enganar era esta a queixa, a quea atitudedos dirigentesfoi a de tornar pública o seu desagravo com os logros cometidos. Infelizmente, osPândegos d'África não tornaram público o modo pelo qual foram enganados, mas é possível que os "africanos de lei", com seus "feitichismos", tivessem desagradado os quefossem mais críticos a tais exibições.

Por certo, as relações entre os organizadores do carnaval eo clube nem sempre eram tão harmoniosas, haja vista as insistentes proibiçõesa tudo que pudesseser caracterizado como africanismo; mas, como costuma ser de praxe, eram restrições que sempre dependiam deimpreci sas avaliações da polícia. Asordens do chefede polícia D omingos G uimarães, em agosto de 1885, ilustram muito bem esta atitude. Ele recomendou aos subdelegados que não consentissem candomblés em seus distritos, pois estavam cassadas todas as licenças para tal divertimento. M isteriosamente, no dia seguinte expediu uma circular informando queo R io Vermelho estava excluído da restrição. ${ }^{34} 0$ que o chefe de polícia nomeava por candomblé e os motivos da exceção ao distrito do Rio Vermelho não são conhecidos, mas o fato demonstra que as regras já eram como são: sempre ao sabor do ânimo das autoridades.

Artista e pesquisador de costumes dos africanos e seus descendentes, $M$ anoel $Q$ uerino ocupava um lugar na frontei ra entreo intelectual e o "colecionador de impressões", que, segundo a elite acadêmica, não utilizava os padrões de cientificidade em vigor. M ais tarde, a sua "ambígua" posição foi definida pelo termo "folclorista". U ma designação capaz de garantir respeitabilidade a alguém que, sendo "autodidata, trabal hando com independência metodológica, sem ligações diretas com as tradições da escola baiana, deixou-se resval ar em fal has esenõesque, decerto modo, tiram de al guns dos seus trabal hoso exato sabor científico" como assinalou Arthur Ramos ao prefaciar, em1938, Costumes Africanos no Brasil ( Q uerino,1988:18). Edison Carneiro disse que as supostas fal has esenões de $M$ anoel $Q$ uerino foram equívocoslevadosasério pelo próprio Arthur Ramos. 
U m desses equívocos relacionava-se ao comentário de $\mathrm{M}$ anoel Q uerino ao desfile dos Pândegos d' África de 1897. Eleviu ali "a reprodução exata" de uma festa com máscaras que acontecia em Lagos. Edison Carneiro foi contundente em sua crítica a Arthur Ramos por ter ele concluído, sob influência de $M$ anoel Q uerino, que "os festejos cíclicos da Costa dos Escravos parecem ter sido a influência principal no carnaval negro na Bahia" (Carneiro,1974:121). A forma como C arneiro expôs a sua crítica é muito interessante. Eleinocentou Q uerino: “um bom observador da vida dos negros na Bahia, mas al guém [que] não tinha boa informação acerca dos costumes originais da África", mas não poupou Ramos "que tendo qualificações de cientista", havia acreditado em tal paralelo ( C arneiro,1974:122). A imagem de mero colecionar de informações eximiu $M$ anoel $Q$ uerino da responsabilidade que cabia ao cientista Arthur Ramos.

$M$ as, deixando de lado o discurso científico da época, vale pensar aqui sobre a continuidade entre a tradição nagô e os Pândegos d'África que tanto irritou Edison Carneiro. A continuidade entre Lagos e Bahia, não só vista como pretendida por $M$ anoel Q uerino, presidente do clube, deixaà mostra uma leitura da ascendência da Bahia na genérica, mas inclusiva, nação nagô. Era como ligação estrita entre a Bahia e a tradição nagô que ele enxergava 0 clube, do qual ele próprio talvez já fizesse parte. ${ }^{35}$

Como assinalou A Bahia, naqueleano de1897, os Pândegos estavam "perfeitamente caracterizados", numa demonstração de queo empenho na "reprodução exata" da festa de L agos tevealgum sucesso. Tratava-se da representação de uma corte de negros fantasiados de nobres a reeditar crenças "africanas". C rítico, mas generoso, N ina Rodrigues ainda comentou que, "da parte dos diretores" do clube, podia haver "ainten ção de reviver tradições" mas, "0 seu sucesso popular está em constituírem el es verdadeiras festas africanas" ( Rodrigues, 1988:100). I nfel izmente não sei se entre os diretores já estava $M$ anoel Q uerino, mas Bibiano C upim certamente, sim. A posição de $\mathrm{N}$ ina R odrigues ao reconhecer o esforço da diretoria, e lamentar o candomblé que el es publicamente promoviam, conta sobre os seus dilemas frente à herança africana na Bahia. A visibilidade desta descendência num disfarce tão revelador trazia à cena carnavalesca uma África mitificada, mas muito possível deser encontradanos desvãos do $\mathrm{G}$ antois, por onde andava tanto $\mathrm{M}$ anoel $\mathrm{Q}$ uerino quanto $\mathrm{N}$ ina Rodrigues e Edison $\mathrm{C}$ arneiro, numa procura pelas sobrevivências da(s) África(s) na Bahia. 
0 que explica tanto as críticas quanto adesões ao desfile dos Pândegos.

J. Lorand M atory discutiu a construção da nação yoruba no Atlântico e, centra a sua abordagem nas casas "nagôs" de candombléno Brasil. N uma crítica ao essencialismo cultural queorientou, e ainda tem orientado, as pesquisas sobre a religiosidade afro-brasileira, 0 autor identificou N ina Rodrigues eseus seguidores como articuladores da comprovação científica da africanidade do candomblé, e mais ainda da pureza racial e cultural dos nagôs. 0 autor informa que os terreiros de candomblé da Bahia foram ambientes propícios para a reificação da suposta superioridade e unidade cultural dos povos yorubas. $\mathrm{N}$ as "tradicionais" casas de candomblé, informantes como $\mathrm{M}$ artiniano Bonfim não só traziam notícias de Lagos, mas também reiteravam a continuidade entrea Bahia e o povo yorubano. ${ }^{36}$ Para J. Lorand $M$ atory, a importância atribuída à preservação de uma cultura ancestral africana, construía aqui a nação dosnagôs, garantindo-Ihes autenticidade. N este sentido, a cultura lida como nagô na Bahia foi o resultado de uma construção transatlântica, em que a circulação entre Lagos e Bahia foi condição imprescindível (M atory, 1999). ${ }^{37}$

Extinto o tráfico, a Áfricana Bahia não podia mais ser refeita através da chegada de contínuas levas de africanos. $M$ as, a sua recriação estava em curso em diversos territórios simbólicos nos quais um variado repertório detradições estivesse disponível. Penso que o clube $\mathrm{N}$ agôs em Folia, por exemplo, trazia para a rua uma interpretação sobre como se podia ser nagô na Bahia. Certamente uma interpretação filtrada por experiências da escravidão, estórias sobreo mundo africano epor "nacionalidades" em construção. Pe quenos "afoxés" como Lordes I deais, organizado pelo dogueiro e ogã do BateFolha, J osé do G udé, provavel mente trazia a público a África que se construía nos seus espaços de inserção (Carneiro,1974:121-123). Conflitos, assimilaçõ̃es e intercâmbios culturais foram e, continuam sendo, infinitos dentro da comunidade afrodescendente. É por conta destemovimento quea presença dos Pândegos d'África e Embaixada Africana não me parece atitudes antagônicas, mas dialógicas.

$N$ ão há notícias sobre possíveis viagens de $M$ anoel $Q$ uerino a Lagos. É bem razoável que a semelhança por el e estabelecida tenha mesmo Ihe ocorrido após relatos de africanos ou de comerciantes habituados a fazer a rota Bahia - Lagos. Aliás, esta foi a conclusão de Edison Carneiro. Afinal, coube aos comerciantes, primeiramente de escravos, e depois de dendê, fumo e produtos reli- 
giosos fazer circular notícias e reinventar a África que se fazia em Lagos, um grande centro de negócios da Costa (C unha, 1985). $\mathrm{N}$ os últimos anos do século XIX, período de franca expansão do poderio inglês, Lagos era uma encruzilhada cultural, onde afro-cubanos, afro-brasileiros, africanos de mais diversas procedências e ingleses se encontravam. J. L orand M atory informa que em 1889, uma em cada sete pessoas residentes em L agos havia morado no B rasil ou em C uba, e se considerarmos a afluência de pessoas do interior do continente e de outros países em busca de bons negócios, podemos imagi nar como a partir de Lagos a África se espal hava pelo mundo navegável (M atory, 1999:84). T amanha presença estrangeira continuamente impactava as leituras acerca do que era a África e os vínculos entre as populações da diáspora. Suponho que para muitos comerciantes afrodescendentes que não se afastavam da Costa, Á frica e Lagos fossem sinônimos numa redefinação territorial e cultural da terra dos ancestrais. 0 que meleva a considerar que na Bahia da época dizer-se nagô fosse, no pósAbolição, o modo mais explícito de dizer-se africano (Rodrigues, 1988: 98).

$\mathrm{N}$ uma infeliz viagem do patacho Aliança, em 1899 para a C osta d'África, os passagei ros foram acometidos por febres fatais, tendo que regressar à Bahia. O s 60 africanos que pretendiam ser repatriados enfrentaram mais uma vez os dissabores datravessia do Atlântico, trazendo de volta mercadorias que deveriam ser entregues aos comerciantes "brasileiros" lá estabelecidos (Rodrigues, 1988:98). Assim que aportou na baía, após o mal ogro da viagem e dos negócios, vários comerciantes reclamaram a posse de seus bens. Entre el es estava a africana Julia $\mathrm{M}$ aria da C onceição, negociante, com comércio estabelecido na freguesia do Passo. ${ }^{38}$ Pertenciam a ela 125 barris defumo em rolo. Júlia devia ser bem informada, mesmo depois que cessou o tráfico, acerca da vida em Lagos, dos conflitos na África e das possibilidades de negócio.

A África ainda chegava à Bahia pelo porto. N este ponto, pareciam concordar Embaixada Africana e os Pândegos d' África. A questão era saber se ela deveria vir na comitiva do rei $M$ enelik ou em meio a mercadorias semelhantes às do comerciante africano J oséF ortunato daC unha, queem 1889 trouxe, entreoutras coisas, "três tabaques sendo um sem coro, uma caixinha de pinho com quinhentos e tantos obis, uma galinha da costa além de 60 panos da costa". ${ }^{39}$ Passado o tempo das revoltas, abolida a escravidão, a rota Bahia-A frica ainda ameaçava. 
0 medo de que a Bahia continuasse a "africanizar-se" no pós-Abolição punha em pânico grande parte da imprensa, que al entou a esperança de que os seus temores fossem amenizados com o fim do tráfico e a deportação dos que não fossem nacionais. Sob o título de África M aster, A Bahia publicou em 1899 os comentários de um "chistoso" e anônimo poeta sobre um sermão proferido em língua nagô por um missionário africano naigreja da Sé. Traduzindo o culto para seus leitores, 0 autor conta que 0 ato foi um apelo em favor dos queviviam "como macacosnasflorestas, nos buracos sem ar, sem luz, sem razão". N a sua tradução dos versos então proferidos pel o missionário, dizia-se:

Vamos, unamo-nos todos, nagôsebrancos da terra, nestepaiz tudo fede, neste paiz tudo berra. Abaixo a tola vaidade, um pouco de piedade!

Venha da choça ou da sala, para os míseros irmãos. Caia a esmola das mãos, a voz do sangue é quem fala.

$\mathrm{N}$ a conclusão 0 autor al ertava que o discurso do missionário era inócuo, porque "na terra do vatapá não há mais quem entenda esseverso". ${ }^{46}$ D enovo, temosaqui um chiste, uma piada com sentidosdúbios: o poeta poderia estar sereferindo a uma ausência de piedade para com a "mísera" África que sobrevivia dos dois lados do oceano, assim como ao gradual desaparecimento dos que pudessem plenamente entender o discurso em nagô. Como já vimos, as duas leituras eram correntes no período etinham em comum uma forte dose de racismo.

Portanto, os discursos racialistas e a extinção dos africanos na Bahia não inquietaram apenas $\mathrm{N}$ ina R odrigues e $\mathrm{M}$ anoel $\mathrm{Q}$ uerino. Autores anônimos e outros mais famosos, como Xavier $\mathrm{M}$ arques, interpretaram a seu modo as mudanças daí decorrentes. ${ }^{41}$ Enquanto comentavam o fim do êxodo africano para o Brasil, os autores releram a própria escravidão, a tirar as suas conclusões sobreos desdobramentos da abolição e da afrodescendência. 0 safricanos ainda se faziam presentes, fosse por uma certa nostal gia evidente em autores como Xavier $M$ arques, fosse por um ansiado alívio pelo fim da "colônia africana" no Brasil.

I magino que africanos como Cecília Adolfo, passados anos da Abolição, ainda incomodavam quando declaravam ser católicos, porém prestar "culto à religião africana, e por esta razão peço que 0 meu enterro obedeça às praxes do rito africano." ${ }^{\prime 2} \dot{E}$ sobre este tipo de nostalgia e incômodo que fala Xavier $M$ arques no seu romance0 Feiticeiro, eépor estarazão queresolvi discuti-lo aqui. 


\section{O s Velhos Africanos e seus M al efícios}

A multidão de negros que se aglomeravam nas ruas em dias de momo foi relida por Xavier $\mathrm{M}$ arques em 0 Feiticeiro. No romance, uma "moça defamília" - Eulália - angustia-se por ter recorrido aos "maléficos rituais" do candomblé para resolver seus problemas sentimentais. Em meio a suas crises de consciência efé ela se dá conta da aproximação do carnaval, o que tornava ainda mais densa a presença do vel ho feiticeiro incumbido deintermediar a sua questão com os "temíveis" "ídolos do santuário africano." $\mathrm{N}$ as palavras do autor: "a ironia desse carnaval acintoso golpeava-lhe a alma" (M arques, 1975:123-124). N a sua imaginação ganhava forma

uma charanga selvagem [na qual]; figurantes velhos, trôpegos, medonhos, obedeciam aosmovimentos deum grande penacho multicor, sacudido pela mão de agigantado africano, cuja boca disforme sorria, num arreganho canino, com a dentadura branquejante sobre 0 arredondado de uma carapuça vermel ha...N egros e negras avançavam numa dança fantástica macabra, a rebramir como feras(ibidem: 123).

Aqui, o texto de Xavier M arques prima pelo pavoroso. 0 recurso de ter relegado à sofrida protagonista a tarefa de contar ao leitor as suas impressões sobre a participação negra no carnaval, permitiu ao autor contrapor o que lhe parecia ser dois universos culturais distintos, mas relacionais, numa sociedade onde tanto uma frágil mocinha mergulhada em conflitos morais, quanto um assombroso africano com seu riso canino eram personagens possíveis. 0 F eiticei ro foi escrito em 1890, quando os jornais locais davam ampla cobertura à ação policial nos candomblés, e ambientado em 1870, período em quea conquista daalforria eraum expedientecada vez maiscomum. É evidentea inten ção do autor em salientar que o mundo dos africanos e de seus descendentes envolvia as vidas de pessoas que tinham valores, hábitos e aspirações muito distintas das vivenciadas por aqueles.

Ao ler 0 F eiticeir ro, nota-se a ênfasena diferenciação dosgrupos sociais que se encontravam e se distinguiam publicamente. Eram ocasiões, a exemplo de um passeio da família de um bemsucedido comerciante do M ercado de Santa Bárbara pelo sítio do $M$ atatu: el es depararam com uma oferenda de adeptos do candomblé ao pé de uma árvore. Diante do assombro da família com tal achado, o comerciante passa a questionar por quetantas ressalvasà fé dos negros, já que os católicos também tinham suas crenças, je- 
juns, retiros e procissões. N outra situação, era o pano da costa que adornava a mesa da sala de visitas do comerciante que surpreendia os personagens; noutra, era a folia de reis com colorido eanimação dos ranchos dos negros. A sociedade branca desenhada por Xavier $M$ arques definia-se pela ambigüidade. Sem isentar-se da crítica à presença dos africanos ao acentuar o incômodo dos batucagês na madrugada e da multidão de pretos nas ruas, restava sempre um tom de sedução pela mística religiosa, presteza e artimanhas da gente de cor da cidade.

O s personagens estão imersos em questões das quais se ocupavam os intelectuais da época. É a estória de um próspero comerciante que, clandestinamente, ocupa o cargo de ogã em um terreiro, de uma moça de cor, costureira, que tenta camuflar as suas origens africanas etem sensações "estranhas" quando ouve o som dos tambores; ou um escriturário ansioso por benesses do estado, uma viúva católica temerosa dos mal efícios africanos, um jovem advogado republicano, um prestigiado comendador que divide a cama com sua criada negra e, é claro, um feiticeiro africano - tio Elesbão.

0 tio Elesbão criado por Xavier $M$ arques não se diferencia muito doslíderes religiosos descritos por $\mathrm{N}$ ina Rodrigues, $\mathrm{M}$ anoel Q uerino e Edison Carneiro. Trata-se de um velho altivo, sempre cercado por um dedicado séqüito, e hábil em estabelecer vínculos com pessoas de privilegiada situação social. Xavier M arques deixa entrever em seu texto a mesma nostal gia experimentada por $\mathrm{N}$ ina Rodrigues em relação à progressiva einevitável extinção dos africanos na Bahia, sem deixar delado o "estado sel vagem" então atribuído aos vel hos e "medonhos" africanos. Q uando um dos personagens, o comerciante eogã Paulo Boto assi stea uma festa no terreiro deElesbão, o ritual o faz pensar que "o mistério da cabala, os gestos do ritual, a beleza do culto não se pronunciavam tanto nas mestiças pardas, quanto nas puras africanas e nas suas filhas de pele azevichada" (ibidem:29). N a leitura de Xavier M arques era 0 africano que melhor encarnava tanto o bizarro capaz de aterrorizar moças de família, quanto a bel eza dos terreiros de candomblé.

$N$ as suas alianças políticas, o africano E lesbão éapresentado como um monarquista "muito contente com o governo e o imperador", pois tinha assegurado que a polícia não iria mais incomodá-lo (ibidem:202). D iante dos debates em torno da questão republicana a posição do africano era clara: temia o novo governo e as mudanças. A o contar sobre uma festa de reis no bairro da lapinha, 0 autor se deteve num rancho com crioulas vestidas com saias 
brancas a dar vivasa Pedro, imperador do Brasil. T radição, servilidade econservação de padrões foram adjetivos atribuídos ao velho Elesbão e sua gente. Em meio às transformações políticas e culturais do período, o africano representava o que estava em vias de ser superado. 0 episódio da sua morte ilustra bem esta questão. 0 cortejo fúnebre de Elesbão levou para as ruas:

N egros africanos, cambai os, patudos, encartuchadosem vel hosredingotes; negras minas, gêges, nagôs e crioulas, umas de trufa branca, outras de carapinha ao sol, com largos panos de chita epanos da Costa, listrados de azul, pelos ombros abaixo, moviam-se com um bando de urubus em direitura às Portas do C armo (ibidem:247).

Enquanto via passar o "andar banzei ro da negraria", a outrora atormentada moça branca que usufruiu os poderes daquele feiticeiro, mostrava-se feliz e indiferente a tamanho espetáculo. 0 feiticeiro morreu, não a incomodava mais. Superadas as dificuldades, cessava a presença do africano. A sua ausência só parecia ser sentida pela costureira tão empenhada em dissimular a sua ascendência. A penas para ela e os aguadeiros reunidos em torno do chafariz a morte do africano parecia representar uma perda.

A nebulosa edecrescente presença dos africanos não mudava apenas a vida da protagonista: na visão de Xavier M arques toda uma nova situação social se insinuava. N o seu texto, ao mesmo tempo em que, paira uma certa nostal gia pelo fim dos africanos, sobressai um otimismo pelas mudanças decorrentes do fim da escravidão na sociedade baiana. Por certo, as expectativas acerca de uma sociedade onde a escravidão não existisse não eram exclusivas dos intel ectuais. Sem negligenciar o caráter progressivo da Abolição no Brasil, a completa extinção desta instituição em 1888 não passou despercebida à população de cor, fosse ela livre, liberta, cativa e/ ou proprietária deescrava. Asrepresentações da África, as reações à decrescente presença dos africanos, as definições acerca das prerrogativas do trabalho livre, as formas de repressão ao repertório cultural afro-brasileiro compunham todo um complexo quadro de referências a partir do qual a numerosa população de cor construía lugares sociais e auto-representações.

Em 1876, vários homens se envolveram em uma confusão num samba no distrito de Pirajá. Tudo começou quando Cosme Ramos pediu um copo de cachaça ao dono da casa, M anoel Libório dos Santos, recebendo em troca uma "porção de petróleo". A atitude do dono da casa foi vista por dois outros homens quetocavam pandeiro. U m deles mostrou-se indignado e disse para $\mathrm{M} \mathrm{a-}$ 
Esperanças de B oaventuras: C onstruções da África eAfricanismos na B ahia...

noel Liborio o seguinte: isso não é coisa que se faça a um cidadão brasileiro. 0 comentário resultou em grandetumulto eum homicídio. Entre os envolvidos, estava um português, operário em uma olaria, dois roceiros e um servente - todos, pardos ou mulatos, moradores na freguesia, exceto o português. $\mathrm{N}$ a maioria dos depoimentos a fala do sambista apareceu como o início da confusão, obviamente estimulada pela cachaça que temperava a farra. 0 argumento utilizado para marcar a impropriedade da atitude do dono da casa é, no mínimo, curioso. ${ }^{43}$

$\mathrm{N}$ ão pretendo aqui especular sobre o que viria a ser cidadania para um grupo de trabal hadores/sambistas na década de 70 do século XIX. M as é inegável que pertencimento eidentidade eram questões que estavam em jogo naquela roda de samba. Eram as mesmas que sustentavam a participação controversa dos clubes africanizados no carnaval, e davam coerência ao texto de Xavier $M$ arques. Em meio à falência do escravismo e construção de uma sociedadetão excludente ehierárquica, a população decor poderia estar buscando livrar-se de marcas escravistas, mas este era um exercício que envolvia a atualização de memórias da África eda escravidão. ${ }^{44}$

A condição de estrangeiros de alguns dos sobreviventes da trágica diáspora africana, a exemplo, de Esperança da B oaventura; a participação dos clubes africanizados; a queixa quanto ao tratamento que cabia a um brasileiro, para mim fazem parte de um mesmo contínuo deslocamento entre África(s)/Brasil e escravidão/ liberdade. E, este, como sugere I ra Berlin trata-se de um movimento nem sempre na mesma direção (Berlin, 1998).

N otas

1. Série Judiciária, Inventários, 1906/1907, Arquivo Público M unicipal de Santo Amaro (doravante APM SA).

2. Série Judiciária, T estamentos, 1876-1890, Arquivo Público Estadual da Bahia (doravanteAPEBA ). O liveira (1997) discute as construções dos nomes de nação no tráfico deescravos para a Bahia, considerando que tais denominações orientaram as relações entre os africanos na diáspora, assi m como as tran sações comerciais entre Brasil e África.

3. O liveira (1988:40) comentou que a proibição foi decorrente das sanções impostas aos africanos após a revolta dos mal ês, em 1835. A autora encontrou apenas três tes- 
W lamyraRibeiro deAlbuquerque

tadoresneste impedimento, o quea levou a concluir ter a lei caído em desuso; contudo, acho importante uma análise dos desdobramentos da lei em comparação aos pedidos de naturalização dos africanos.

4. Cunha (1985) e O liveira (1988) discutem as diversas restrições sociais impostas aos africanos libertos como medidas de controle.

5. Correio de $\mathrm{N}$ otícias, $28 / 2 / 1900$.

6. A Bahia, 23/2/1908

7. Cunha (2001:171) analisa que no Rio deJ aneiro "quase exclusivo dos cordões eram, no entanto, títul osque remetiam a etnias e origens africanas". Ver também V ieira FiIho (1995).

8. Digo população de cor, visto a hipótese razoável de que estes grupos eram majoritariamenteformados por afrodescendentes. Robert C on rad (1972: 283-285) indica que entre 1886-1887 foram matriculados apen as 1.001 escravos sexagenários. E, segundo J oão J osé R eis, se em 1857 os africanos representavam 100\% dos ganhadores escravos elibertos deSalvador, já em 1887, dos trabal had ores reunidos em cantos $49 \%$ eram africanos, sendo que $74 \%$ tinham mais de 60 anos (Reis, 1993:31; 2000:200-201).

9. Sobre as preocupações e tentativas de controle da população pobrena B ahia no sécuIo XIX, ver Fraga Filho (1996).

10. Vieira Filho (1995), discute as formas e motivos de repressão aos batuques.

11. Correio de N otícias, 27/1/1897.

12. Sessão J udiciária, Testamentos, 1900-1910, APEBA.

13. Q uerino (1988: 66-72) sereferiu aos malêscomo um grupo devalores morais rígidos e ritos muito distinto dos demais grupos africanos.

14. Correio de $N$ otícias, 8/3/1900.

15. Correio de Notícias, 27/2/1897.

16. Pratt (1999) aborda os empreendimentos colonialistas europeus no século XVIII. $N$ a sua pesquisa a autora apreen de os rel atos de viagem, diários e compêndios dehistória natural como fontes para entender os encontros culturais entre colonizadores e colonizados.

17. 0 M enelick, 17 outubro de 1915.

18. Para Kim Butler o candomblé caracterizou-se no período com espaço de construção deuma consciência afro descen dente devalorização e preservação da cultura africana (Butler, 1998: 191). H á uma excelente discussão sobre esta questão em Dantas (1988).

19. Existe uma vasta bibliografia que aborda os investimentos no carnaval carioca. 0 título mais recente é o importante texto de C unha (2001).

20. APEBA, Sessão J udiciária, Testamentos e Inventários. N ina R odrigues ao tratar dos negros bantus informou que "moram alguns negros austrais em pequenas roças nas vizinhanças da cidade, em Brotas, no Cabula" (1988:114). Para uma interessante discussão sobre as formas de moradias dos africanos no Rio de J aneiro ver Soares, C . E. (2001).

21. Correio de N otícias, 18/2/1898.

22. Esta tem sido uma discussão recorrente na historiografia baiana, só para citar al guns títulos: Ferreira Filho (1998-1999), Soares, C. M . ( 2001).

\section{2}


Esperanças de B oaventuras: C onstruções da África eAfricanismos na B ahia...

23. A Bahia, 26/2/1900.

24. A Bahia, 16/2/1906.

25. A Bahia, 20/2/1906.

26. Infelizmente não conseguir descrições do desfile deste clube.

27. Correio de Notícias, 25/2/1897.

28. A Bahia, 4/3/1897.

29. Sessão J udiciária, Inventários e T estamentos, 1933, APEBA

30. Idem, 1928, APEBA.

31. Idem, 1921, APEBA.

32. É preciso investigar com mais cuidado as filiações partidárias de $M$ anoel $Q$ uerino; em A B ahia de outrora o autor se refere ao I mpério e à Corte com uma evidente nostal gia.

33. A Coisa, 8/4/1900.

34. Correspondências expedidas aos subdelegados, maço 5869, Série Polícia, APEBA

35. N ão consegui localizar ainda a composição da diretoria do clube antes de 1900, portanto não sei quando $M$ anoel $Q$ uerino passou a integrá-la.

36. Ruth $L$ andes ( $\mathrm{s} / \mathrm{d})$ fez várias referências àinfluência deM artiniano sobre pesquisadores importantes como $\mathrm{N}$ ina Rodrigues e Edison $\mathrm{C}$ arneiro.

37. O s títulos seguintes são fundamentais neste debate: Cunha (1985) e Araújo, (1998/1999: 83-110).

38. Sessão J udiciária, Inventários e T estamentos, 1908, APEBA.

39. Idem, 1889, APEBA

40. A Bahia, 8/3/1899.

41. Xavier M arques (1861-1942) foi um dos principais escritores e jornalistas baianos no fim do século XIX. D avid Salles, um dos sues biógrafos, fez o seguinte comentário sobre o seu trabalho: "D eve ser considerado um escritor fim-de-século, portador de heranças do romantismo, realismo e debates da poesia científica realista concomitante com as mudanças do regime econômico e social" (M arques, 1998:10).

42. Sessão J udiciária, testamentos e inventários, 1908, APEBA.

43. Idem, 1876, APEBA.

44. Sobre as estratégias dos ex-escravos para livrar-se das heranças escravistas no mundo do trabal ho, ver M attos (1998).

\section{Referências Bibliográficas}

ARAÚ JO , U biratan C astro de (1998/1999). "1846: U m Ano na Rota Brasil-Lagos: N e gócios, N egociantes e 0 utros Parceiros". Afro-Ásia, no 21, pp. 83-110.

BACELAR, J efferson (2001). A H ierarquia das Raças: N egros e Brancos em Salvador. Rio de Janeiro, Pallas.

BERLIN , I ra (1998). M any Thousands G one: The First T wo C enturies of First Slavery in $\mathrm{N}$ orth America. C ambridge, $\mathrm{H}$ arvard U niversity Press.

BRAGA, Júlio Santana (1987), Sociedade Protetora dos D esvalidos. U ma Irmandade de Cor. Salvador, Ianamá.

BU T LER, Kim D . (1998), Freedoms Given, Freedom W on: Afro-BraziliansPost-A bolition São Paulo and Salvador. N ew Brunswick, N . J., Rutgers U niversity Press. 
W lamyra Ribeiro deAlbuquerque

CARNEIRO, Edison (1974). Folguedos Tradicionais. Rio de Janeiro, Conquista.

CON RAD, R obert (1972). TheD estruction of Brazilian Slavery (1850-1888). Berkeley, University of $C$ alifornia Press.

CU N H A, M anoela Carneiro da (1985). N egros Estrangeiros. Os Escravos Libertos e sua Volta à África. São Paulo, Brasilense.

CU N H A, M aria C lementina P. (2001). E cos da Folia. U ma H istória Social do Carnaval Carioca entre 1880-1920. São Paulo, Companhia das Letras.

D AN TAS, Beatriz G óis(1988). Vovó N agô ePapai Branco. U soseA busosda Á frica no Brasil. Rio de Janeiro, Graal.

FELIX, Anísio \& NERY, M oacyr (1993). Bahia, Carnaval. Salvador, s/e.

FRAG A FILH O, V alter (1996). M endigos, M ol eques e Vadios no Século XIX. São Paulo, H ucitec/Salvador, EDUFBA.

FERREIRA FILH O , Alberto H eráclito (1998-1999). “D esafricanizar as Ruas: ElitesL etradas, M ulheres Pobres e C ultura Popular em Salvador, 1890-1937". Afro- Á sia, no 21, pp. 239-256.

FRY, Peter et alii (1998). "N egros e Brancos no Carnaval da Velha República". In J. J . Reis (org.) , Escravidão e I nvenção da Liberdade. Estudos sobre o N egro no Brasil. São Paulo, Brasiliense, pp. 232-263.

LAN D ES, Ruth (1967). A Cidade das M ulheres. São Paulo, Civilização Brasileira.

MARCUS, H arold G. (1975). The Life and Time of Menelick II - Ethiopia (1844-1913). Oxford, Clarendon Press.

MARQUES, Xavier (1975). O Feiticeiro. (3ª ed.). São Paulo, GRD.

M AT O RY, J. Lorand ( 1999), "T heEnglish Professors of Brazil: O $n$ the D iasporic R oots of the Yorubá $\mathrm{N}$ ation". Comparative Studiesin the Society and $\mathrm{H}$ istory, vol. 41, no 1 , pp. 72-103.

M ATT O S, H ebeM aria (1998), D asC oresdo Silêncio: O sSignificadosda Liberdadeno Sudeste Escravista - Brasil, séc. XIX. (2 ${ }^{\mathrm{a}}$ ed.). Rio Janeiro, N ova Fronteira.

O LIVEIRA, M aria Inês Cortês (1988), 0 Liberto seu M undo e os 0 utros - Salvador, 1790-1890. São Paulo, Corrupio.

_ (1997). "Q uem Eram os N egros da Guiné? A O rigem dos Africanos na Bahia". Afro-Ásia, no 19-20, pp. 37-74.

Q U ERIN O , M anoel (1918). 0 Colono Preto como Fator da Civilização Brasileira. Salvador, I mprensa $O$ ficial.

_ (1988). C ostumes Africanos no Brasil. ( $2^{\text {a }}$ ed.). Recife, M assananga.

REIS, J oão J osé ( 1986), Rebelião E scrava no Brasil: A H istória do Levante dos M alês. São Paulo, Brasiliense.

_ (1993). "A G reve N egra em 1857 na Bahia". Revista da U SP, nำ18, pp. 8-30.

_ (2000), "D e O Iho no C anto: Trabal ho de Rua na Bahia na V éspera da Abolição". Afro-Ásia, no 24, pp. 199-242.

RO D RIGUES, N ina (1935). 0 Animismo Feitichista dos N egros Baianos. (5ª ed.). São Paulo, Civilização Brasileira.

_ (1988). O sA fricanosnoBrasil. (7- ed.). São Paulo, C iaEd. N acional / Brasília, U nB.

VIEIRA FILH O, Raphael Rodrigues (1995). A Africanização do C arnaval de Salvador. A Recriação do Espaço C arnaval esco (1876-1930). D issertação, PU C -São Paulo.

\section{4}


Esperanças de B oaventuras: C onstruções da África eAfricanismos na Bahia...

PRATT, M ary Louise (1999). Os O Ihos do I mpério: Relatos de Viagem eT ransculturação. Bauru, EDUSC.

SO ARES, C arlos Eugênio (2001). A Capoeira Escrava e outras T radi ções Rebeldes no Rio de Janeiro ( 1808-1850). Campinas, Editora da U nicamp.

SO ARES, Cecília M oreira (2001), "A N egra na Rua, O utros C onflitos". In C. Sardenberg (org.), Fazendo $\mathrm{G}$ ênero na H istoriografia Baiana. Salvador, FFCH /U FBA.

U ZO IGWE, Godfrey N. (1985). "Partilha Européia e Conquista da África”. H istória Geral da África. A África sob D ominação Colonial (1880-1935). São Paulo. 